\title{
Estomatite Ulcerosa - 0 Desafio Diagnóstico
}

\author{
Ulcerative Stomatitis - \\ A Diagnostic Challenge
}

Methotrexate (MTX) is an immunomodulating agent used in many autoimmune diseases. Its toxicity is dosedependent and affects rapidly dividing tissues such as gastrointestinal tract and bone marrow ${ }^{1}$. Oral ulcerative stomatitis can be found in up to $14 \%$ of patients but its wide histopathologic spectrum, which ranges from nonspecific ulceration to lichenoid reactions, represents a diagnostic challenge ${ }^{2}$. A 65 -year-old woman with rheumatic arthritis, stop attending medical care since 2012 but kept a daily dose of $10 \mathrm{mg}$ of methotrexate associated with $5 \mathrm{mg} /$ day of folic acid. In 2015 , she was admitted in the Medicine Department after developing multiple shallow areas of ulceration in the floor of the mouth, buccal and labial mucosa and soft palate (Figure 1). Extra-oral observation showed lip ulceration. The other physical examination was irrelevant. She had bicytopenia (27000 leukocytes and 82000 platelets), C-Reactive protein of $143 \mathrm{mg} / \mathrm{L}$ (normal $<7.5 \mathrm{mg} / \mathrm{L}$ ) and creatinine of $1.6 \mathrm{mg} / \mathrm{dL}$ (normal<1.3 mg/dL). Liver function test and chest $x$-ray were normal. Serology for Human Immunodeficiency Virus 1 and 2 was negative. MTX was discontinued with resolution of the oral ulceration and analytical abnormalities. She was dismissed to her rheumatologist and restarted MTX therapy $(10 \mathrm{mg} /$ weekly) 2 years later without recurrence of adverse events. In conclusion, adherence to methotrexate is the key to attaining disease remission/low disease activity and low toxicity profile ${ }^{3}$. A careful medical and pharmacological history is mandatory and clinicians should be aware of this drug possible side effects ${ }^{3}$.

\section{References}

1. Troeltzsch M, von Blohn G, Kriegelstein S, Woodlock T, Gassling V, Berndt $R$, Troeltzsch M. Oral mucositis in patients receiving low-dose methotrexate therapy for rheumatoid arthritis: report of 2 cases and literature review.Oral Surg Oral Med Oral Pathol Oral Radiol. 2013 May; 115(5):e28-33.

2. Kalantzis A, Marshman Z, Falconer DT, Morgan PR, Odell EW. Oral effects of low-dose methotrexate treatment.Oral Surg Oral Med Oral Pathol Oral Radiol. 2005 Jul; 100(1):52-62.

3. Cannon GW, Mikuls TR, Hayden CL, Ying J, Curtis JR, Reimold AM, Caplan L, Kerr GS, Richards JS, Johnson DS, Sauer BC. Merging Veterans Affairs rheumatoid arthritis registry and pharmacy data to assess methotrexate adherence and disease activity in clinical practice.Arthritis Care Res (Hoboken). 2011 Dec; 63(12):1680-90.
Figure 1. Ulcerative Stomatitis

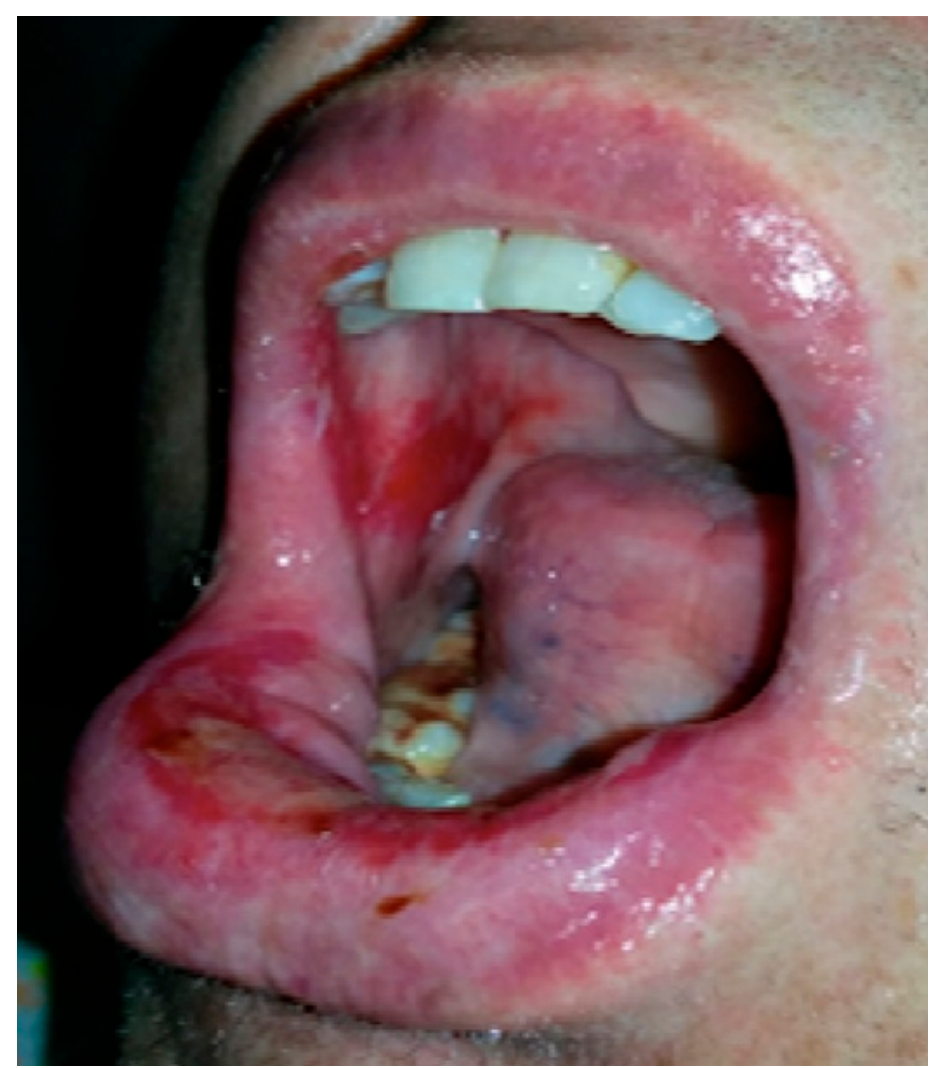

Diagnosis:

\section{Ulcerative Stomatitis: Oral effect of methotrexate}

\section{Liliana Torres, Diana Pereira Anjos \\ Centro Hospitalar do Tâmega e Sousa}

Correspondencia: lilianacitorres@hotmail.com

Cómo citar este artículo: Torres L, Pereira Anjos D

Estomatite Ulcerosa - 0 Desafio Diagnóstico. Galicia Clin 2019; 80 (2): 33

Recibido: 05/06/2018; Aceptado: 11/06/2018

http://doi.org/10.22546/52/1677 